\title{
STATISTIK DEMOGRAFI DIAPHANIA INDICA SAUNDERS (LEPIDOPTERA: CRAMBIDAE)
}

\author{
Ita Fitriyana ${ }^{1}$, Damayanti Buchori ${ }^{1}$, Ali Nurmansyah ${ }^{1}$, Rosichon Ubaidillah $^{2}$, \& Akhmad Rizali ${ }^{3}$ \\ ${ }^{1}$ Departemen Proteksi Tanaman, Fakultas Pertanian, Institut Pertanian Bogor \\ Jl. Kamper, Kampus IPB Dramaga, Bogor 16680 \\ ${ }^{2}$ Bidang Zoologi Pusat Penelitian LIPI, Bogor \\ J1. Raya Jakarta - Bogor Km.46 Cibinong, Bogor 16911 \\ ${ }^{3}$ Jurusan Hama dan Penyakit Tumbuhan, Fakultas Pertanian, Universitas Brawijaya \\ J1. Veteran, Malang 65145 \\ E-mail: ita.fitriyana@ymail.com
}

\begin{abstract}
Demographic statistic of Diaphania indica Saunders (Lepidoptera: Crambidae). Diaphania indica is a pest of Cucumis sativus $\mathrm{L}$. The information about the biology of $D$. indica is needed to determine appropriate pest management strategies. The aim of this study was to study the biology and life cycle of $D$. indica. The study was conducted by observing life stage development of $D$. indica, such as life cycle, head width and body length. The life table was determined by calculating mortality of $D$. indica individuals and fecundity at each age. Mortality and fecundity data of $D$. indica were then used to calculate the parameters of population growth including gross reproduction rate (GRR), net reproductive rate (Ro), mean generation time $(\mathrm{T})$ and and intrinsic rate of increase $(\mathrm{r})$. The results show that the life cycle of $D$. indica is about 25.7 days, while egg stadium $=3.2$ days, larval stadium $=13.5$ days, pupal stadium $=7.9$ days, imago stadium $=8.6$ days, and preoviposition period $=3.9$ days. GRR of $D$. indica is 263 individuals per generation. Ro $=51$ individuals per female per generation. $T$ is 31.3 days and the innate capacity for increase $(r)=0.1$ individual per female per day.
\end{abstract}

Key words: Diaphania indica, life cycle, life table

\section{ABSTRAK}

Statistik demografi Diaphania indica Saunders (Lepidoptera: Crambidae). Diaphania indica adalah hama pada tanaman mentimun Cucumis sativus L. Informasi mengenai biologi dan siklus hidup diperlukan untuk strategi pengendalian hama. Tujuan dari penelitian ini adalah untuk mengetahui biologi dan siklus hidup $D$. indica. Pengamatan biologi terkait siklus hidup D. indica dilakukan dengan mengamati setiap tahap perkembangan hidup $D$. indica, meliputi waktu yang diperlukan dan ukuran tubuh pada setiap stadium. Penelitian neraca kehidupan dilakukan dengan mencatat mortalitas individu $D$. indica dan keperidian setiap individu imago setiap harinya. Data mortalitas dan keperidian $D$. indica dimasukkan ke dalam tabel neraca kehidupan yang kemudian digunakan untuk menghitung parameter pertumbuhan populasi $D$. indica, meliputi laju reproduksi kotor (GRR), laju reproduksi bersih (Ro), rataan masa generasi (T), dan laju pertumbuhan instrinsik (r). Hasil penelitian menunjukkan bahwa siklus hidup $D$. indica pada tanaman mentimun memerlukan waktu 26,6 hari, dengan lama stadium telur 3,2 hari; stadium larva 13,5 hari, stadium pupa 7,9 hari, stadium imago 8,6 hari dan masa praoviposisi imago 3,9 hari. GRR $D$. indica adalah 263 individu/generasi, Ro sebesar 51 individu/induk/generasi, T selama 31,3 hari, dan r sebesar 0,1 individu/ induk/hari.

Kata kunci: Diaphania indica, neraca kehidupan, siklus hidup

\section{PENDAHULUAN}

Pengetahuan mengenai aspek-aspek demografi merupakan salah satu langkah awal dalam mempelajari perkembangan suatu populasi serangga. Demografi adalah analisis kuantitatif karakteristik suatu populasi, terutama hubungannya dengan pola pertumbuhan populasi, hubungan ketahanan, dan pergerakan populasi. Hal ini sangat erat hubungannya dengan dinamika populasi namun penekanannya agak berbeda, demografi lebih memusatkan pada pola perkembangan, kelahiran, kematian, dan pergerakan, sementara itu sebab dan akibat dari fenomena ini dipelajari dalam dinamika populasi. Aspek demografi suatu populasi terdapat dalam neraca kehidupan. Neraca kehidupan merupakan teknik menghitung angka kelahiran dan kematian suatu populasi. Neraca tersebut adalah ringkasan pernyataan tentang kehidupan individu populasi atau kelompok. Dari 
data yang dihasilkan dapat dihitung berapa lama harapan hidup yang masih tersisa suatu individu (Price, 1984). Ada dua tipe neraca kehidupan yaitu yang bersifat spesifik umur atau neraca kehidupan horisontal dan yang bersifat spesifik waktu atau neraca kehidupan vertikal (Bellows et al., 1992). Neraca kehidupan horisontal mencakup penghitungan yang berulang terhadap suatu kelompok (kohort) tunggal yang terdiri dari individu yang sama umurnya sepanjang waktu. Sedangkan neraca kehidupan vertikal adalah data diambil pada suatu kejadian tunggal ketika diasumsikan bahwa semua generasinya sudah saling lingkup dengan sempurna oleh karena kelas umur secara simultan adalah sama. Neraca kehidupan merupakan riwayat perkembangan kohort yang bersifat dinamis (Tarumingkeng, 1992). Carey (1993) mengungkapkan bahwa neraca kehidupan yang dirancang dengan baik dapat meningkatkan pemahaman mengenai proses-proses yang terjadi di dalam suatu populasi yang dapat digunakan untuk memprediksi struktur populasi dan pengaruh interaksi antar spesies terhadappopulasi tersebut. Informasi biologi dan neraca kehidupan diperlukan dalam menentukan strategi pengendalian hama.

Salah satu hama yang berpotensi menimbulkan kerusakan pada tanaman adalah hama ulat daun Diaphania indica Saunders (Lepidoptera: Crambidae). MacLeod (2005) menyatakan bahwa $D$. indica merupakan salah satu hama pada pertanaman mentimun di Asia dan Afrika. Hama ini juga ditemukan menyerang mentimun di Indonesia (Asikin, 2004). Larva D. indica memakan daun, batang muda yang lunak dan menggerek buah. Kerusakan yang paling merugikan adalah jika larva menyerang buah mentimun. Pada buah yang terserang ditemukan lubang pada permukaan buah, menyebabkan buah menjadi cepat busuk sehingga tidak layak untuk dikonsumsi dan dijual (CABI, 2005). Dalam upaya pengendalian hama $D$. indica dibutuhkan informasi dasar seperti informasi biologi dan neraca kehidupan dari serangga tersebut. Pengetahuan mengenai berbagai aspek biologi yang diperlukan antara lain meliputi perilaku, siklus hidup, perkembangan, fisiologi, dan reproduksi (DeBach, 1973). Penelitian yang berkaitan dengan biologi dan statistika demografi dari $D$. indica perlu dilakukan untuk menunjang keberhasilan dalam pengendalian hama ulat daun $D$. indica. Tujuan dari penelitian ini adalah untuk mempelajari biologi dan statistika demografi $D$. indica di laboratorium. Penelitian ini diharapkan dapat memberikan informasi biologi $D$. indica yang dapat digunakan sebagai input dalam merancang dan mengambil keputusan yang tepat dalam mengendalikan $D$. indica.

\section{METODE PENELITIAN}

Tempat dan Waktu. Penelitian dilaksanakan di Laboratorium Pengendalian Hayati, Departemen Proteksi Tanaman, Fakultas Pertanian IPB, Bogor. Penelitian ini dilaksanakan dari bulan Februari sampai dengan Juni 2014.

Pemeliharaan Masal Diaphania indica. Serangga D. indica dikumpulkan dari lahan pertanaman mentimun milik petani di Desa Cihideung Udik, Kecamatan Ciampea, Kabupaten Bogor. Larva atau pupa yang didapat dari lapangan selanjutnya dipelihara di laboratorium untuk dikembangbiakkan. Larva dipelihara dalam wadah plastik berukuran 14 × 9 x $7 \mathrm{~cm}$. Larva yang telah menjadi pupa kemudian ditempatkan pada wadah plastik (diameter $=3 \mathrm{~cm}$, tinggi $=18 \mathrm{~cm}$ ) sampai menjadi imago. Pakan untuk imago berupa larutan madu $20 \%$. Imago dipelihara hingga menghasilkan telur dan mati. Telur yang dihasilkan dipindahkan ke dalam tabung plastik (diameter $=9 \mathrm{~cm}$, tinggi $=12 \mathrm{~cm}$ ). Larva yang muncul dipelihara hingga menjadi imago.

\section{Pengamatan Siklus Hidup D. indica di Lapangan.} Untuk mempelajari siklus hidup $D$. indica di lapangan, sebanyak 100 larva dipilih secara acak pada tanaman mentimun. Larva instar I diberi tanda dan diamati setiap hari. Pengamatan dilakukan dengan mencatat masih ada atau tidaknya larva, masih hidup atau sudah mati. Larva yang masih hidup difoto dengan kamera digital Casio EX-ZS5. Larva difoto setiap hari untuk mengetahui ukuran panjang tubuh dan lebar kepala larva. Penentuan stadia larva dilakukan dengan mempelajari ukuran larva yang diperoleh dari foto yang kemudian diukur menggunakan program TPS DIG version 2. Hasil digitasi kemudian dikonversi dengan Microsoft Excel 2010 menjadi ukuran panjang tubuh dan lebar kepala. Untuk penentuan stadia instar larva digunakan pengukuran lebar kepala yang kemudian di analisis dengan distribusi frekuensi berdasarkan metode yang digunakan Chen \& Seybold (2013). Jumlah larva yang hidup, dan mati diamati dan dicatat perkembangannya setiap hari hingga menjadi imago dan menghasilkan telur. Lama stadia larva, pupa dan imago, panjang dan lebar ukuran pupa, serta jenis kelamin imago yang muncul juga dicatat.

Pengamatan Kohort $\boldsymbol{D}$. indica. Kohort merupakan kelompok individu yang lahir dalam interval waktu yang hampir sama (Begon et al., 2008). Pengamatan kohort D. indica dilakukan dalam empat tahap yang disesuaikan 
dengan fase perkembangan $D$. indica, yaitu fase telur, larva, pupa dan imago.

Pengamatan Stadia Telur D. indica. Telur $D$. indica yang digunakan sebagai populasi awal kohort berasal dari peletakan telur oleh imago betina hasil perbanyakan. Pengamatan dimulai dengan mempersiapkan 100 telur yang berasal dari lima ekor betina ke dalam toples plastik. Telur-telur diinkubasi hingga menetas. Telur yang digunakan merupakan telur yang diletakkan pada hari yang sama. Pengamatan dilakukan setiap hari dengan mencatat jumlah larva instar I yang muncul dari toples plastik. Larva instar I yang muncul kemudian dipindahkan dan dipelihara untuk pengamatan lama stadia larva. Pengamatan stadia telur mencakup lama stadia telur, jumlah telur yang diletakkan, jumlah telur yang menetas dan persentase penetasan. Persentase penetasan dihitung dengan menggunakan rumus:

$$
\% \text { Penetasan }=\frac{\text { Jumlah telur yang menetas }}{\text { Total jumlah telur }} \times 100 \%
$$

Pengamatan Lama Stadia Larva $D$. indica. Larva instar I yang digunakan untuk pengujian ini merupakan larva yang muncul dari 100 telur yang digunakan pada awal pengamatan. Larva yang muncul dimasukkan kedalam wadah plastik berukuran 14 x $9 \mathrm{x}$ $7 \mathrm{~cm}$ yang berisi pakan daun mentimun. Pengamatan lama stadia larva dilakukan dengan mengamati jumlah larva yang hidup dan yang mati. Perkembangan larva dicatat setiap hari sampai larva menjadi pupa. Pengamatan tahap ini memberikan data lama stadia larva, distribusi umur instar dan laju kesintasan larva.

Pengamatan Lama Stadia Pupa D. indica. Pengamatan lama stadia pupa dilakukan sejak pupa terbentuk sampai pupa menjadi imago. Pupa yang terbentuk dimasukkan ke dalam wadah plastik (diamater $=3 \mathrm{~cm}$, tinggi $=18 \mathrm{~cm}$ ). Pengamatan ini menghasilkan data lama stadia pupa.

Pengamatan Imago $D$. indica. Tahap terakhir dari pengamatan kohort adalah pengamatan imago. Imago yang muncul dari pupa pada pengamatan sebelumnya dipelihara dalam wadah plastik yang berisi kapas yang telah dibasahi dengan larutan madu 20\% sebagai pakan $D$. indica dan daun mentimun sebagai media peletakan telur imago $D$. indica. Satu ekor imago betina yang muncul kemudian dipaparkan dengan satu ekor imago jantan. Pemaparan dilakukan agar imago jantan dan betina dapat berkopulasi sehingga menghasilkan telur. Pemaparan dilakukan setiap hari dan dihentikan ketika seluruh imago mati. Pengamatan ini menghasilkan data siklus dan lama hidup imago jantan dan betina, periode praoviposisi, umur betina saat pertama kali meletakkan telur, periode oviposisi, dan fekunditas.

Analisis Data. Data mengenai kemampuan hidup dan fekunditas disusun dalam bentuk tabel neraca kehidupan (life table). Parameter demografi yang dihitung menurut Birch (1948) dalam Kurniawan (2007) meliputi:

\section{Laju produksi kotor $(\mathrm{GRR})=\sum m_{x}$}

2. Laju produksi bersih $\left(\mathrm{R}_{\mathrm{o}}\right)=\sum l_{x} m_{x}$

3. Laju pertumbuhan instrinsik $\left(\mathrm{r}_{\mathrm{m}}\right)=\sum l_{x} m_{x} e^{-r m x}=1$ dengan $\mathrm{r}_{\text {awal }}=\left(\ln \mathrm{R}_{\mathrm{o}}\right) / \mathrm{T}$

4. Rataan masa generasi $(\mathrm{T})=\frac{\sum X l_{x} m_{x}}{\sum l_{x} m_{x}}$

5. Populasi berlipat ganda (DT) $=\ln (2) / T$

Statistik neraca kehidupan kemudian disusun menggunakan metode Jackknife. Jackknife adalah metode pengambilan contoh ulang (resampling) yang digunakan untuk estimasi bias dan menduga standar deviasi (Quenouille, 1949). Prinsip dasar dari metode Jackknife terletak pada perhitungan suatu statistik secara berulang dengan mengeluarkan satu atau lebih pengamatan dari suatu sampel (n) yang ditetapkan, sehingga menghasilkan sampel terpisah yang masingmasing memiliki besar ukuran $\mathrm{n}-1$ atau $\mathrm{n}-\mathrm{d},(\mathrm{d} \leq \mathrm{n})$. Pengambilan ulang sampel dalam penelitian ini dilakukan sebanyak 50 kali.

\section{HASIL DAN PEMBAHASAN}

Siklus Hidup Diaphania indica. Siklus hidup $D$. indica terdiri dari empat fase yaitu telur, larva, pupa dan imago. Larva $D$. indica terdiri dari lima instar (instar I, II, III, IV dan V). Stadia dan ukuran masing-masing fase perkembangan Diaphania indica dapat dilihat pada Tabel 1.

Telur $D$. indica diletakkan secara berkelompok di bawah permukaan daun mentimun (Gambar 1). Telur memiliki rata rata panjang $0,7 \mathrm{~mm}$ dan lebar $0,4 \mathrm{~mm}$. Telur menetas setelah diletakkan 1 sampai 3 hari. Telur berbentuk bulat pipih. Pada hari pertama diletakkan telur berwarna kuning transparan, kemudian warna telur secara perlahan berubah menjadi kuning pekat yang menandakan telur akan segera menetas.

Hasil analisis distribusi frekuensi ukuran lebar kepala menunjukkan bahwa larva $D$. indica mengalami lima instar yakni instar I hingga instar V. Tubuh larva terdiri dari 3 ruas toraks dengan 2 pasang spirakel dan 
10 ruas abdomen dengan 8 pasang spirakel. Larva memakan daun, batang yang bertekstur lunak dan buah mentimun. Tubuh larva instar I berwarna hijau kekuningan dengan kepala berwarna hijau muda (Gambar 2A). Ukuran rata-rata panjang tubuh 3,3 mm dan lebar kepala 0,3 $\mathrm{mm}$. Larva instar I yang baru muncul tidak langsung aktif bergerak tetapi bersembunyi terlebih dahulu di antara tulang daun. Setelah dua hari larva instar I berubah warna menjadi kehijauan dan larva mulai aktif bergerak dan memakan bagian tengah menuju bagian tepi daun. Lama stadia larva instar I adalah 2 sampai 4 hari.

Tubuh larva instar II memiliki warna kehijauan yang lebih pekat dibandingkan dengan larva instar I (Gambar 2B). Pada larva instar II mulai muncul garis putih pada bagian dorsal larva. Ukuran rata-rata panjang tubuh larva instar II adalah 5,7 $\mathrm{mm}$ dengan rata-rata lebar kepala 0,4 mm. Pada fase ini larva sudah lebih aktif bergerak dibandingkan dengan larva instar I . Lama stadia larva instar II adalah 2 sampai 5 hari.

Larva instar III dan IV berwarna hijau dengan dua garis berwarna putih di sepanjang tubuh bagian dorsal, dan kepala berwarna hijau (Gambar 3A dan 3B). Larva instar III memiliki panjang $8,1 \mathrm{~mm}$ dengan lebar kepala $0,7 \mathrm{~mm}$. Larva instar IV memiliki ukuran ratarata panjang $10,5 \mathrm{~mm}$ dengan rata-rata lebar kepala 0,9 $\mathrm{mm}$. Pada kedua fase ini larva lebih aktif makan daun dan batang lunak. Larva instar III dan IV memiliki lama stadia yang sama yaitu berkisar 2 sampai 4 hari.

Tabel 1. Rata-rata lama stadia, panjang tubuh dan lebar kepala larva Diaphania indica

\begin{tabular}{lcc}
\hline \multirow{2}{*}{ Fase } & \multicolumn{2}{c}{ Lama stadia (hari) } \\
\cline { 2 - 3 } & Selang $(\mathrm{n})$ & Rata-rata \pm galat \\
\hline Telur & $3-4(100)$ & $3,2 \pm 0,9$ \\
Larva Instar 1 & $2-5(100)$ & $3,4 \pm 0,7$ \\
Larva Instar 2 & $2-4(93)$ & $2,5 \pm 0,7$ \\
Larva Instar 3 & $2-4(79)$ & $2,7 \pm 0,6$ \\
Larva Instar 4 & $2-5(68)$ & $2,4 \pm 1,3$ \\
Larva Instar 5 & $1-5(68)$ & $2,6 \pm 1,4$ \\
Pupa & $6-12(62)$ & $7,8 \pm 1,4$ \\
Jantan : & & \\
Lama hidup & $5-13(27)$ & $8,6 \pm 2,3$ \\
Betina : & & \\
Lama hidup & $8-14(29)$ & $10,6 \pm 1,8$ \\
Siklus hidup & $23-32(29)$ & $25,7 \pm 3,1$ \\
Umur pertama meletakkan telur & $26-35(29)$ & $3,6 \pm 3,0$ \\
Masa praoviposisi & $2-6(29)$ & $6,5 \pm 0,8$ \\
Masa oviposisi & $4-10(29)$ & $103,3 \pm 67,0$ \\
Fekunditas & $37-309(29)$ &
\end{tabular}
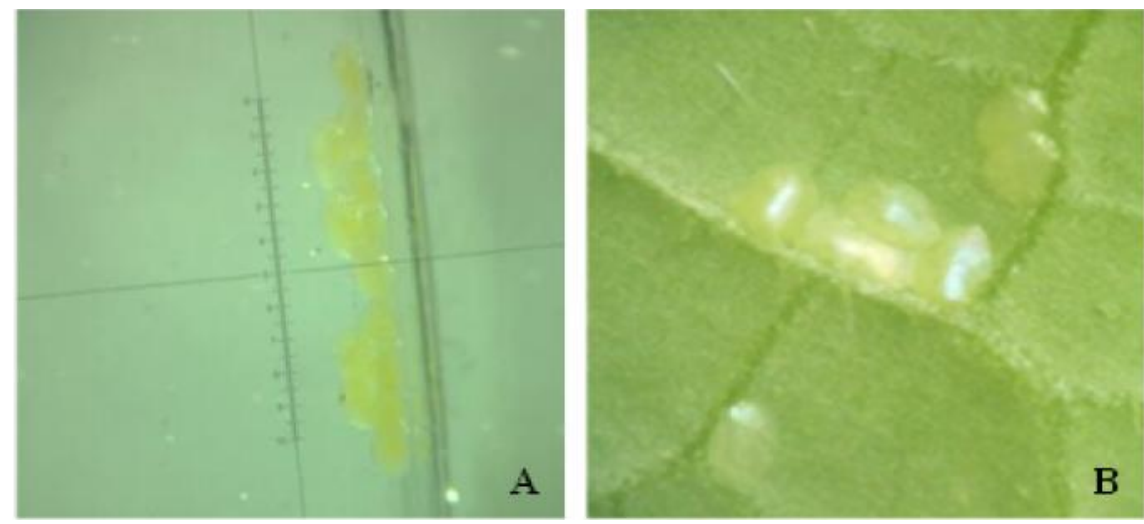

Gambar 1. Telur Diaphania indica di bawah mikroskop (A) dan di bawah permukaan daun (B) 
Larva instar V berwarna hijau dengan dua garis putih sepanjang tubuh yang semakin jelas dan kepala berwarna hijau kekuningan. Panjang tubuh dan lebar kepala larva instar V adalah 12,0 mm dan 1,4 mm. Pada fase ini larva mulai memasuki masa prapupa yang berlangsung 1 sampai 2 hari. Menjelang masa prapupa tubuh larva berubah warna menjadi lebih pucat. Masa prapupa ditandai dengan menurunnya aktivitas dan kemampuan makan. Larva mulai menyelubungi tubuhnya dengan menjalin benang-benang yang dihasilkan dari mulutnya (Gambar 4). Biasanya larva tersebut melipat daun dan kemudian bersembunyi di dalam lipatan daun tersebut. Saat fase prapupa larva akan mengalami penyusutan ukuran tubuh sehingga terlihat lebar dan gemuk. Lama stadia larva instar V adalah 1 sampai 5 hari.
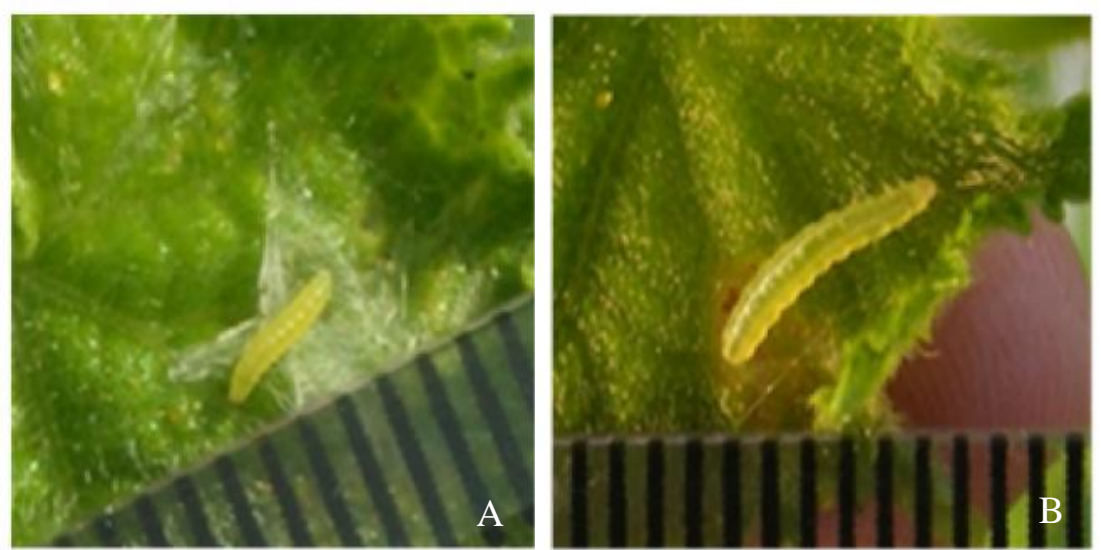

Gambar 2. Larva Diaphania indica instar I (A) dan instar II (B)
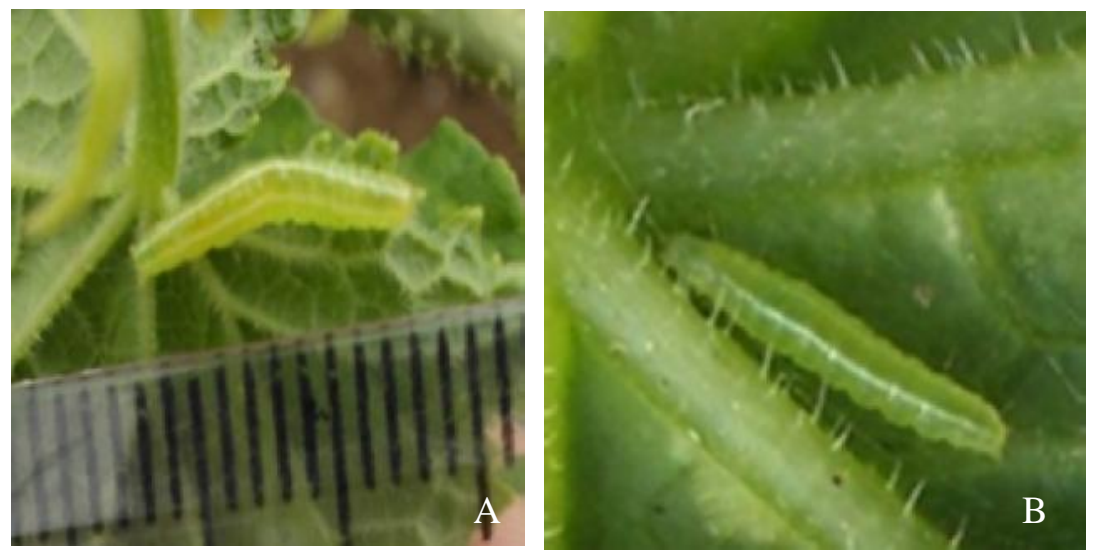

Gambar 3. Larva Diaphania indica instar III (A) dan instar IV (B)

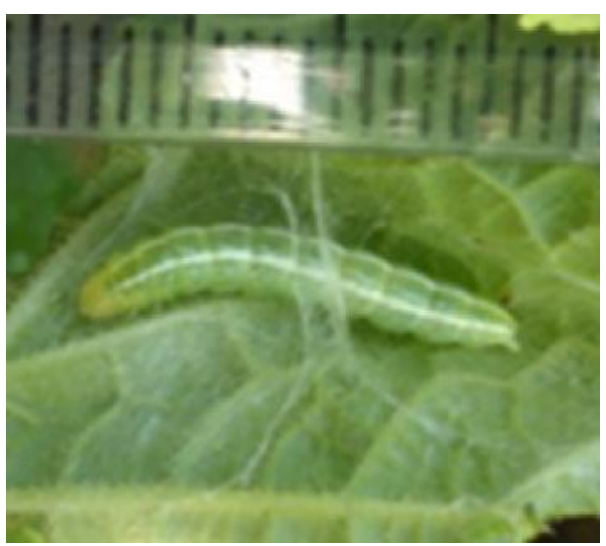

Gambar 4. Larva Diaphania indica instar V yang akan memasuki periode prapupa 
Pupa berwarna coklat mengkilap. Tipe pupa $D$. indica adalah obtekta. Bagian bakal antena, alat mulut, bakal sayap dan bakal tungkai dapat dilihat dengan jelas. Rata-rata panjang tubuh pupa 11,3 $\mathrm{mm}$ dan lebar tubuh pupa 2,5 mm (Gambar 5). Perbedaan pupa jantan dan betina dapat dilihat dari karakteristik morfologinya. Pupa jantan memiliki bentuk ujung abdomen kerucut dan memiliki pola warna gelap terang yang jelas antar ruas abdomen, sedangkan pupa betina memiliki bentuk ujung abdomen yang lebih ramping serta pola warna gelap terang antar ruas abdomen yang kurang jelas (Gambar 5). Selain itu, pada pupa betina terdapat celah pada sternum ruas abdomen terakhir. Pupa yang akan menjadi imago ditandai dengan perubahan warna dari coklat menjadi kehitaman. Stadia pupa berkisar antara 6 sampai 12 hari dan biasanya terdapat dalam gulungan daun.

Imago yang baru terbentuk berwarna putih kekuningan (krem). Sayap berwarna putih dengan pita berwarna coklat gelap di sepanjang pinggiran sayap. Warna sayap antara jantan dan betina hampir sama.
Imago jantan dan betina dapat dibedakan melalui morfologi abdomennya. Pada abdomen imago betina terdapat rumbai (bulu-bulu halus) berwarna kuning dengan jumlah yang lebih banyak, dan ukuran abdomen yang lebih besar dibandingkan dengan imago jantan (Gambar 6). Panjang larva umumnya berkaitan dengan jenis kelamin dari imago $D$. indica. Larva $D$. indica dengan panjang 12,8-15,0 mm umumnya menjadi imago betina, sedangkan larva dengan panjang $11,0-12,7 \mathrm{~mm}$ menjadi imago jantan. Ukuran lebar rentang sayap jantan adalah 12,6 mm dan sayap betina 13,3 mm. Lama stadia jantan 6 sampai 13 hari, sedangkan lama stadia betina 8 sampai 14 hari.

\section{Masa Praoviposisi, Oviposisi dan Fekunditas} D. indica. Masa praoviposisi betina $D$. indica berkisar antara 2 sampai 6 hari. Telur diletakkan berkelompok di sepanjang permukaan bawah tulang daun. Banyaknya telur dalam satu helai daun dapat mencapai 71 butir telur/ hari. Imago dapat bertelur hingga 6 hari. Selama

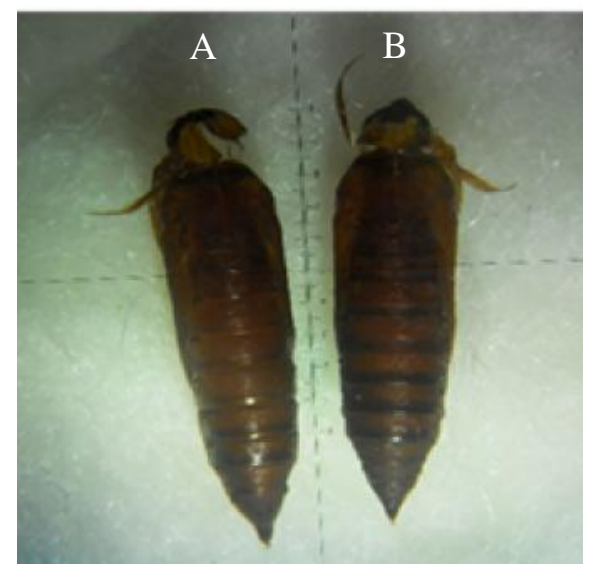

Gambar 5. Pupa Diaphania indica jantan (A) dan betina (B)
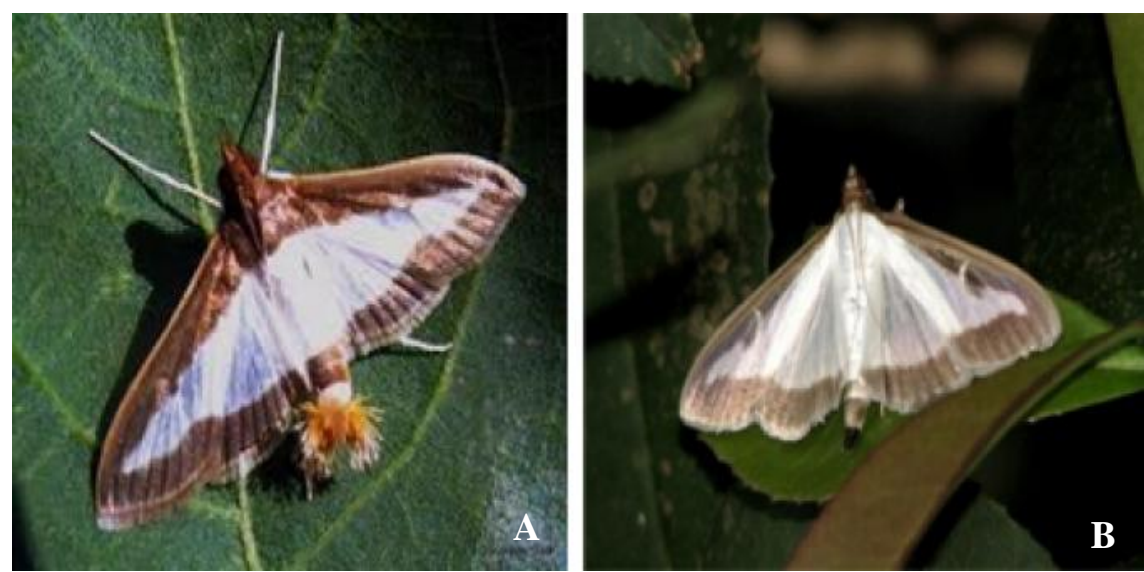

Gambar 6. Imago Diaphania indica betina (A) dan jantan (B) 
hidupnya imago betina mampu menghasilkan 309 butir telur.

Neraca Kehidupan $\boldsymbol{D}$. indica. Neraca kehidupan $D$. indica digunakan untuk mengetahui laju perkembangan populasi serta proses-proses lain yang terjadi di dalam populasi $D$. indica di laboratorium. Berdasarkan perhitungan neraca kehidupan dapat diperoleh informasi berbagai hal mengenai kehidupan D. indica, salah satunya kurva kesintasan. Kurva kesintasan (survivorship) menggambarkan peluang individu $D$. indica yang hidup pada semua stadia mulai dari telur, larva, pupa, dan imago $\left(1_{x}\right)$, dan fekunditas dari imago betina per hari $\left(\mathrm{m}_{\mathrm{x}}\right)$. Price (1984) menjelaskan bahwa bentuk kurva kesintasan ini diperlukan untuk dapat membantu memahami strategi reproduksi populasi serangga.

Sintasan dan Fekunditas. Sintasan atau peluang hidup $D$. indica diperoleh dari pengamatan harian yang dilakukan dari fase telur hingga menjadi dewasa. Kurva sintasan $D$. indica menggambarkan bahwa peluang hidup mulai menurun sejak individu berumur 6 hari. Kurva kesintasan $D$. indica menunjukkan peluang hidup yang rendah pada awal perkembangan diikuti dengan peluang hidup tinggi seiring dengan bertambahnya umur serangga (Gambar 7). Menurut Price (1984) terdapat tiga kurva keberhasilan hidup serangga di alam, yaitu tipe I, II, dan III. Kurva tipe I menggambarkan peluang hidup yang tinggi (kematian rendah) pada awal perkembangan organisme kemudian menurun secara perlahan seiring pertambahan umur, tipe II menggambarkan peluang hidup yang konstan, dan tipe III menggambarkan peluang hidup yang lebih rendah pada awal perkembangan organisme kemudian meningkat secara perlahan seiring pertambahan umur. Hasil pengamatan dari 100 serangga $D$. indica menunjukkan bahwa kurva perkembangan hidup serangga ini termasuk tipe III yakni jumlah keturunan yang dihasilkan tinggi dengan tingkat keberhasilan hidup yang rendah pada awal perkembangan kemudian meningkat seiiring dengan pertumbuhan serangga. Begon \& Mortimer (1981) menyatakan bahwa pola hidup seperti ini sering ditemukan pada sebagian spesies serangga. Morgan et al. (2001) menjelaskan bahwa neraca kehidupan dipengaruhi oleh beberapa faktor yaitu spesies, inang, kondisi iklim tempat penelitian, dan metode perbanyakan serangga (rearing) yang digunakan. Penelitian ini dilakukan di laboratorium dengan jumlah makanan yang disediakan tidak terbatas dan bebas dari faktor musuh alami.

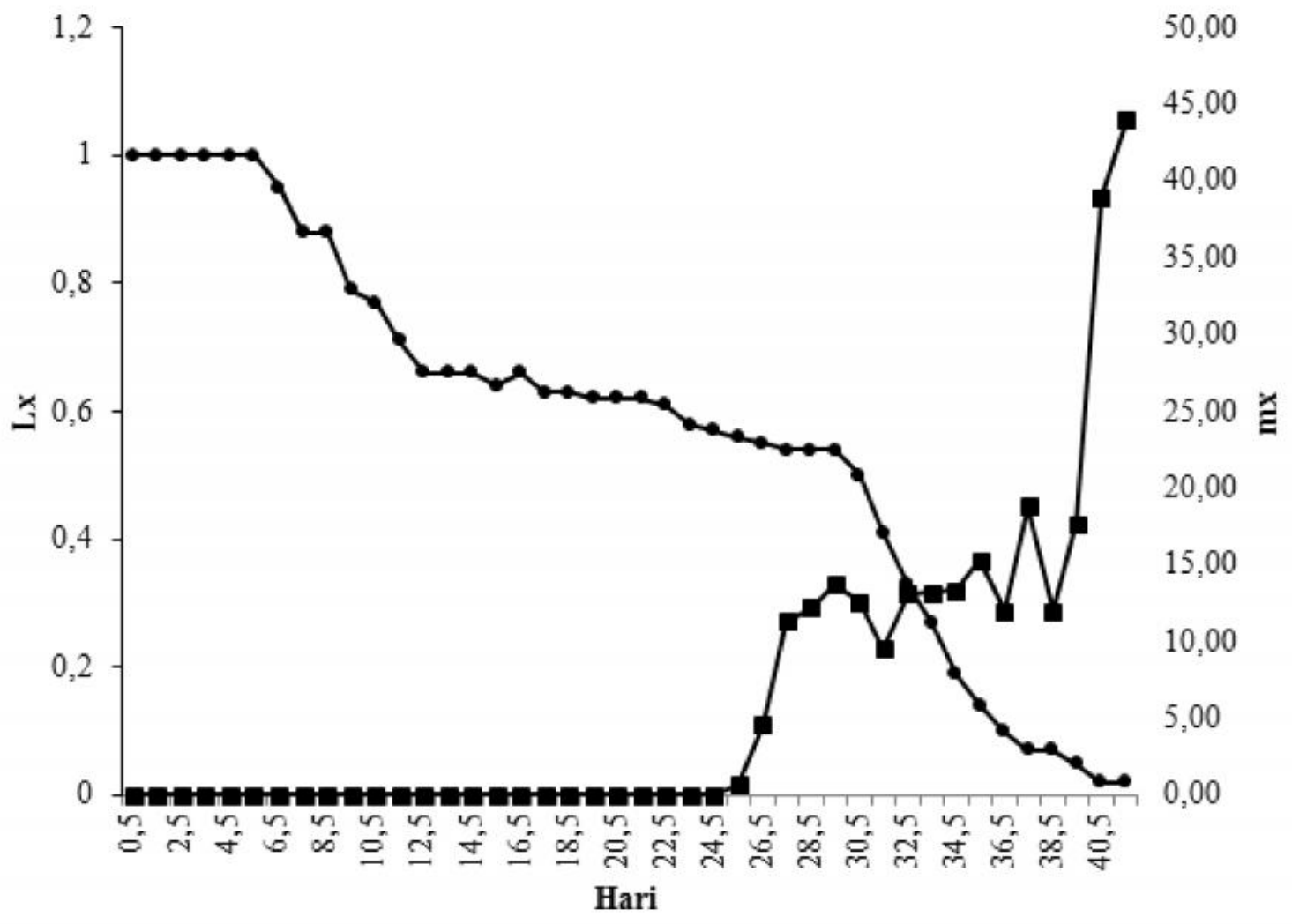

Gambar 7. Kurva sintasan dan fekunditas Diaphania indica 
Fekunditas imago betina dapat diketahui dengan cara menghitung banyaknya telur yang diletakkan setiap harinya. Nilai mx menunjukkan banyaknya telur yang dihasilkan oleh imago betina yang berumur $\mathrm{x}$ hari setelah memperhitungkan nisbah kelamin. Dari kurva juga dapat dilihat bahwa peneluran terjadi setelah hari ke 26 atau 3 hari setelah $D$. indica menjadi imago. Velasco \& Walter (1993) menyatakan bahwa keberhasilan perkembangan serangga dan fase reproduktif serangga sangat dipengaruhi oleh kualitas makanan.

Parameter demografi $D$. indica yang meliputi laju reproduksi kotor (GRR), laju reproduksi bersih (Ro), laju pertambahan instrinsik $\left(\mathrm{r}_{\mathrm{m}}\right)$, rataan lama generasi $(\mathrm{T})$, dan waktu berlipat ganda (doubling time) (DT) dapat dilihat pada Tabel 2.

Laju reproduksi kotor (GRR) menggambarkan rataan jumlah keturunan betina per induk yang dihasilkan oleh individu $D$. indica yang hidupnya mencapai umur maksimal. Nilai GRR D. indica adalah 263 menunjukkan bahwa $D$. indica mampu menghasilkan keturunan sebesar 263 individu/induk/generasi.

Laju reproduksi bersih (Ro) D. indica menunjukkan bahwa rataan banyaknya keturunan betina yang dihasilkan oleh seekor induk betina adalah 51,8 betina/induk/generasi atau dapat dikatakan bahwa populasi $D$. indica dapat berlipat sebanyak 52 kali dalam setiap generasinya. Menurut Price (1997) suatu populasi akan bertambah jika memiliki nilai Ro > 1 dan stabil jika Ro $=1$. Tingginya angka pertumbuhan serangga apabila berada pada kondisi lingkungan yang optimum dapat menyebabkan serangga tersebut dapat berkembang dengan cepat menjadi hama yang menyebabkan kerugian secara ekonomi, seperti kehilangan hasil dan kematian tanaman. Nilai Ro dan GRR menunjukkan tingkat kesesuaian antara serangga dengan tanaman inang, semakin tinggi nilai Ro dan GRR menunjukkan semakin tinggi tingkat kesesuaian serangga dan tanaman inang, sebaliknya nilai Ro dan GRR yang rendah menunjukkan tingkat kesesuaian serangga dan tanaman inang yang rendah pula.

Nilai $r_{m}$ menggambarkan laju pertambahan instrinsik pada keadaan sumber daya yang tidak terbatas dan dihitung dengan asumsi bahwa populasi memiliki nilai $1_{x}$ dan $m_{x}$ yang tetap serta kematian hanya terjadi oleh faktor fisiologi (Price 1997). Nilai $r_{m}$ yang tinggi dapat diartikan bahwa individu akan banyak mengalami kematian pada populasi dilapangan. Nilai $\mathrm{r}_{\mathrm{m}} D$. indica adalah sebesar 0,1. Brewer (1979) menjelaskan bahwa tinggi rendahnya nilai $r$ dipengaruhi oleh jumlah keturunan per periode perkembangan, jumlah yang bertahan hidup dan selama masa reproduktif, usia saat reproduktif dimulai dan lama usia reproduktif.

Nilai rata-rata masa generasi $(\mathrm{T})$ menggambarkan waktu yang dibutuhkan sejak telur diletakkan sampai saat imago betina yang berasal dari telur tersebut menghasilkan keturunannya. Nilai T yang semakin kecil menunjukkan semakin cepat suatu organisme untuk berkembang biak. Nilai T dari $D$. indica sebesar 31,3 menunjukkan bahwa dalam waktu 31,3 hari individu betina $D$. indica mampu menghasilkan keturunan kembali. Berdasarkan nilai tersebut dapat diperkirakan bahwa dalam 1 tahun $D$. indica mampu menghasilkan 12 generasi semakin kecil nilai T maka semakin cepat waktu suatu individu untuk berkembang biak.

Doubling time atau waktu yang dibutuhkan untuk populasi D.indica menjadi berlipat ganda (DT) adalah 5,5 hari. Nilai DT yang tinggi dapat menyebabkan meningkatnya laju reproduksi kotor (GRR) dan nilai laju reproduksi bersih (Ro) dalam satuan waktu tertentu. Menurut Birch (1948) dalam Kurniawan (2007), nilai berlipat ganda yang tinggi pada suatu populasi, dapat menyebabkan penurunan sumber daya lingkungan dan mempengaruhi nilai laju pertambahan intrinsik $\left(\mathrm{r}_{\mathrm{m}}\right)$.

Harcout (1969) menyatakan bahwa neraca kehidupan bukanlah nilai akhir dari analisis dinamika populasi, tetapi sekedar penampilan sistematik dari data ketahanan hidup, mortalitas dan fekunditas dalam populasi. Fungsi utama dari data ini adalah untuk memberikan informasi tentang gambaran kemampuan hidup suatu serangga pada kondisi lingkungan tertentu. Keseluruhan hasil pengamatan demografi dari $D$. indica mengungkapkan bahwa $D$. indica merupakan serangga dengan kemampuan perkembangan populasi yang tinggi dan laju pertumbuhan yang cepat, hal ini dapat dilihat dari tingginya nilai laju reproduksi, doubling time, rataan generasi serta pola kesintasan dari $D$. indica.

Tabel 2. Statistik demografi Diaphania indica di laboratorium

\begin{tabular}{clc}
\hline No. & \multicolumn{1}{c}{ Parameter } & Rataan \pm galat \\
\hline 1. & Laju reproduksi kotor (GRR) & $263,3 \pm 2,5$ \\
2. & Laju reproduksi bersih ( $\left.\mathrm{R}_{\mathrm{o}}\right)$ & $51,8 \pm 0,9$ \\
3. & Laju pertumbuhan intrinsik $\left(\mathrm{r}_{\mathrm{m}}\right)$ & $0,1 \pm 0,0$ \\
4. & Rataan lama generasi (T) (hari) & $31,3 \pm 0,1$ \\
5. & Doubling time (DT) (hari) & $5,5 \pm 0,0$ \\
\hline
\end{tabular}




\section{SIMPULAN}

Siklus hidup Diaphania indica pada tanaman mentimun memerlukan waktu 25,7 hari, dengan kurva keberhasilan hidup tipe III dimana pada pola ini jumlah keturunan yang dihasilkan tinggi dengan tingkat keberhasilan hidup yang rendah pada awal perkembangan kemudian meningkat seiring dengan pertumbuhan serangga. Neraca kehidupan $D$. indica menunjukkan bahwa $D$. indica merupakan serangga yang memiliki tingkat perkembangan yang cepat, tingkat bertahan yang tinggi dan kapasitas reproduksi yang sangat besar, sehingga $D$. indica dapat berpotensi menjadi hama primer dan menyebabkan kerusakan yang signifikan dalam jumlah besar pada tanaman ekonomi penting, apabila tidak dilakukan penanganan secara tepat yang dilaksanakan sesuai waktunya.

\section{SANWACANA}

Penelitian ini dibiayai oleh Direktorat Pendidikan Tinggi (Dikti) melalui Hibah Kompetensi, Institut Pertanian Bogor tahun 2013-2014. Terima kasih kepada Amanda Mawan, S.P., M.Si. dan Ibu Adha Sari, S.P. atas bantuan analisis dan teknis, serta kepada Bapak Darmawan atas bantuan identifikasi serangga parasitoid sehingga penelitian ini dapat berjalan dengan lancar.

\section{DAFTAR PUSTAKA}

Asikin S. 2004. Alternatif pengendalian hama serangga sayuran ramah lingkungan di lahan lebak. Laporan Tahunan Balai Penelitian Pertanian Lahan Rawa (Balitra). Banjarbaru.

Begon M \& Montimer M. 1981. Population Ecology: a Unified Study of Animals and Plants. Sunderland Sinauer Associated, Massachussetts.

Begon M, Townsend CR, \& Harper JL. 2008. Ecology: From Individuals to Ecosystems. 4th edition. Blackwell Publishing, Oxford.

Bellows Jr TS, Van Driesche RG, \& Elkinton JS. 1992. Life-table construction in the evaluation of natural enemies. Annu. Rev. Entomol. 37: 587-612.

Brewer R. 1979. Principles of Ecology. W.B Sounders Co, Philadelphia.

[CABI] Centre for Agriculture and Bioscience International. 2005. Corp Protection Compendium 2005 [CD-ROM]. CABI. Wallingford.
Carey JR. 1993. Applied Demography for Biologist with Special Emphasis on Insect. pp. 11-41. Oxford University Press, New York.

Chen Y \& Seybold SJ. 2013. Application of a frequency distribution method for determining instars of the beet armyworm (Lepidoptera: Noctuidae) from widths of cast head capsules. J. Econ. Entomol. 106(2): 800-806.

DeBach P. 1973. The scope biological control. In: DeBach P (Ed). Biological Control of Insect Pest and Weeds. pp. 3-20. Chapman and Hall Ltd., London.

Harcourt DG. 1969. The development and use of life tables in the study of natural insect population. Annu. Rev. Entomol. 14: 175-196.

Kurniawan HA. 2007. Neraca kehidupan kutukebul, Bemisia tabaci Gennadius (Hemiptera: Aleyrodidae) biotipe-B dan non-B pada tanaman mentimun (Cucumis sativus L.) dan cabai (Capsicum annuum L.). Tesis. Sekolah Pasca Sarjana, Institut Pertanian Bogor, Bogor.

MacLeod A. 2005. Pest Risk Analysis for Diaphania indica. Central Science Laboratory, Sand Hutton York.

Morgan D, Walters KFA, \& Aegerter JN. 2001. Effect of temperature and cultivar on pea aphid, Acyrthosiphon pisum (Hemiptera: Aphididae) life history. Bull. Entomol. Res. 91(1): 47-52.

Price PW. 1997. Insect Ecology. $3^{\text {th }} \mathrm{ed}$. John Wiley \& Sons, New York.

Price PW. 1984. Insect Ecology. $2^{\text {nd }}$ ed. John Wiley \& Sons, New York.

Quenouille MH. 1949. Approximate tests of correlation in time series. J. R. Stat. Soc. B11(1): 68-84.

Tarumingkeng RC. 1992. Dinamika Pertumbuhan Populasi Serangga. Institut Pertanian Bogor, Bogor.

Velasco LRI \& Walter GH. 1993. Potential of host switching in Nezara viridula (Hemiptera: Pentatomidae) to enhance survival and reproduction. Environ. Entomol. 22(2): 326-333. 